\title{
KLASTERISASI KABUPATEN/KOTA DI JAWA TENGAH BERDASARKAN INDIKATOR KINERJA PEMBANGUNAN
}

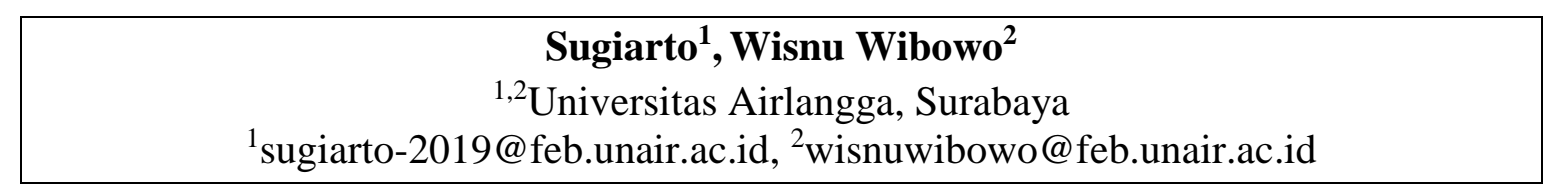

Diterima: Februari 2020; Direvisi Pertama: Maret 2020; Direvisi Kedua: April 2020;

Disetujui: April 2020

\begin{abstract}
The problem of inequality in development between regencies/cities in Central Java still occurs even though economic development in the province is quite successful. This study aims to cluster regions based on development performance indicators of human, infrastructure, and economic to support regional-based policy making. Principal component analysis (PCA) and factor analysis are used to reduce development performance variables that are correlated, while cluster analysis is used to cluster the regions. From PCA and factor analysis of development performance formed 3 human factors, 3 infrastructure factors, and 2 economic factors, while cluster analysis produced 5 regencies/cities clusters. Development performance of human is high, infrastructure is very high, and economy is high owned by Cluster 1, which consists of 4 cities. Cluster 2, which consists of 1 city, characterized by development performance of human is very high, infrastructure is high, and economy is high. Cluster 3, which covers 7 regencies, has development performance of human is very low, infrastructure is medium, and economy is medium. Cluster 4, which consists of 12 regencies, characterized by development performance of human is medium, infrastructure is low, and economy is low. Ten other regencies and one city are located in Cluster 5 characterized by development performance of human is high, infrastructure is high, and economy is low.
\end{abstract}

\section{Keyword: inequality, development performance, cluster analysis}

\begin{abstract}
Abstraksi. Masalah ketimpangan pembangunan antar kabupaten/kota di Jawa Tengah masih terjadi meskipun pembangunan ekonomi di provinsi ini cukup berhasil. Studi ini bertujuan mengklasterisasi wilayah berdasarkan indikator kinerja pembangunan manusia, infrastruktur, dan ekonomi untuk mendukung pengambilan kebijakan berbasis wilayah. Principal Component Analysis (PCA) dan analisis faktor digunakan untuk mereduksi variabel kinerja pembangunan yang saling berkorelasi, sedangkan analisis cluster digunakan untuk mengklasterisasi wilayah. Dari PCA dan analisis faktor kinerja pembangunan terbentuk 3 faktor manusia, 3 faktor infrastruktur, dan 2 faktor ekonomi, sedangkan analisis cluster menghasilkan 5 klaster kabupaten/kota. Kinerja pembangunan manusia tinggi, infrastruktur sangat tinggi, dan ekonomi tinggi dimiliki oleh Klaster 1, yang terdiri dari 4 kota. Klaster 2 yang terdiri dari 1 kota, memiliki karakteristik kinerja pembangunan manusia sangat tinggi, infrastruktur tinggi, dan ekonomi sangat tinggi. Klaster 3 yang mencakup 7 kabupaten, memiliki kinerja pembangunan manusia sangat rendah, infrastruktur sedang, dan ekonomi sedang. Klaster 4 yang terdiri dari 12 kabupaten, memiliki karakteristik kinerja pembangunan manusia sedang, infrastruktur rendah, dan ekonomi rendah. Sepuluh kabupaten dan satu kota lainnya berada pada Klaster 5 dengan ciri-ciri kinerja pembangunan manusia tinggi, infrastruktur tinggi, dan ekonomi rendah.
\end{abstract}

Kata kunci: ketimpangan, kinerja pembangunan, analisis cluster 


\section{PENDAHULUAN}

Pada mulanya, pembangunan dipandang sebagai gejala ekonomi yang ditandai dengan pertumbuhan pendapatan nasional bruto per kapita (Todaro \& Smith, 2012). Pandangan ini menunjukkan bahwa pembangunan hanya mencakup masalah aspek ekonomi, seperti: apa dan berapa produk yang harus dihasilkan; siapa dan bagaimana menghasilkan produk itu; dan untuk siapa produk itu dihasilkan (Samuelson, 1955 dalam Tarigan, 2005). Pandangan ini juga mengabaikan heterogenitas waktu dan spasial atau ruang (lokasi). Oleh karenanya, muncul pandangan ekonomi baru yang menyatakan bahwa keberhasilan pembangunan ditentukan oleh ukuran kemiskinan, pengangguran, dan ketimpangan (Todaro \& Smith, 2012). Tarigan (2005) menyatakan bahwa ketimpangan dan konsentrasi merupakan penentu berhasilnya pembangunan regional.

Pelaksanaan pembangunan regional yang hanya mengejar pencapaian target pertumbuhan ekonomi menyebabkan terjadinya ketimpangan infrastruktur, sosial, ekonomi, dan sumber daya manusia (Dadibhavi, 2019). Pembiaran terjadinya ketimpangan atau kesenjangan hasil pembangunan di suatu wilayah akan berakibat pada ketidakstabilan ekonomi dan sosial, bahkan politik dan keamanan di wilayah itu. Oleh karena itu, klasterisasi wilayah berdasarkan indikator kinerja pembangunan diperlukan untuk mempermudah pengambil kebijakan dalam melakukan program pengurangan ketimpangan hasil pembangunan.

Ada beberapa penelitian tentang ketimpangan pembangunan dan klasterisasi wilayah. Pompili (1994) meneliti struktur dan kinerja daerah yang kurang berkembang di Komunitas Eropa dengan menggunakan analisis cluster dan diskriminan. Hasilnya Komunitas Eropa dikelompokkan menjadi tiga klaster wilayah berdasarkan variabel struktur industri, kewirausahaan manufaktur, modal manusia, aksesibilitas dan infrastruktur, diseconomies eksternal, dan pendapatan per kapita.

Kronthaler (2005) melakukan klasterisasi Jerman Timur dan Jerman Barat berdasarkan kemampuan ekonomi wilayah. Hasilnya kemampuan ekonomi di kedua wilayah tersebut tidak sebanding. Variabel yang digunakan ialah aplikasi paten, biaya untuk litbang, pekerja dengan pendidikan S1, wiraswasta, pengusaha, pekerja sektor industri, pekerja sektor jasa, migrasi neto, investasi sektor industri, investasi di kota, aksesibilitas regional, produk domestik bruto (PDB), dan tingkat pengangguran.

Spencer, Vinodrai, Gertler, \& Wolfe (2009) menggunakan analisis cluster untuk mengelompokkan wilayah kota berdasarkan kinerja industri. Hasilnya ialah ada prevalensi positif klaster industri terkait dengan tingkat pendapatan dan pertumbuhan lapangan kerja.

Goletsis \& Chletsos (2011) meneliti kesenjangan regional dan pola pembangunan menggunakan analisis cluster pada data profil sosial-ekonomi di wilayah Yunani. Hasilnya tidak memberikan bukti kuat untuk konvergensi wilayah Yunani.

Keberhasilan pembangunan Jawa Tengah ditentukan oleh keberhasilan pembangunan di kabupaten/kotanya. Oleh karenanya, visi, misi, dan sasaran pembangunan kabupaten/kota ini harus sejalan dengan visi, misi, dan sasaran pembangunan provinsi.

Keberhasilan kinerja pembangunan setidaknya ditentukan oleh tiga hal. Pertama, kinerja pembangunan manusia, karena manusia pada hakekatnya adalah inti 
dari tujuan pembangunan. Kedua, kinerja pembangunan infrastruktur, karena infrastruktur dapat memperlancar aksesibilitas antar daerah. Ketiga, kinerja pembangunan ekonomi, karena dapat digunakan sebagai ukuran kemakmuran penduduk di suatu wilayah (Widaryoko, 2011).

Capaian beberapa variabel makro pembangunan Jawa Tengah tahun 2018, yakni: pertumbuhan ekonomi 5,32 persen; produk domestik regional bruto (PDRB) riil per kapita 27,29 juta rupiah; tingkat kemiskinan 11,19 persen; tingkat pengangguran terbuka 4,51 persen; rasio Gini 0,357; dan indeks pembangunan manusia (IPM) 71,12 (BPS, 2019). Berbagai capaian ini menunjukkan bahwa Jawa Tengah cukup berhasil melaksanakan pembangunan wilayahnya. Meskipun demikian, jika ditinjau dari capaian kinerja pembangunan antar kabupaten/kotanya, masih terdapat ketimpangan atau kesenjangan sebagaimana terlihat pada Tabel 1.

Tabel 1.

Capaian Beberapa Indikator Kinerja Pembangunan, 2018

\begin{tabular}{|c|c|c|c|c|}
\hline Variabel & Jawa Tengah & Indonesia & Terendah & Tertinggi \\
\hline Pertumbuhan ekonomi (\%) & 5,32 & 5,17 & $\begin{array}{c}\text { Kab. Cilacap } \\
(3,05)\end{array}$ & $\begin{array}{c}\text { Kota Semarang } \\
(6,52)\end{array}$ \\
\hline $\begin{array}{l}\text { PDB/PDRB riil per kapita } \\
\text { (juta Rp) }\end{array}$ & 27,29 & 39,34 & $\begin{array}{l}\text { Kab. Pemalang } \\
\quad(13,30)\end{array}$ & $\begin{array}{l}\text { Kab. Kudus } \\
\quad(82,48)\end{array}$ \\
\hline Tingkat kemiskinan $(\%)$ & 11,19 & 9,66 & $\begin{array}{c}\text { Kota Semarang } \\
(4,14)\end{array}$ & $\begin{array}{c}\text { Kab. Wonosobo } \\
(17,58)\end{array}$ \\
\hline $\begin{array}{l}\text { Tingkat } \\
\text { Terbuka (\%) }\end{array}$ & 4,51 & 5,34 & $\begin{array}{l}\text { Kab. Boyolali } \\
(2,16)\end{array}$ & $\begin{array}{c}\text { Kab. Tegal } \\
(8,45)\end{array}$ \\
\hline Rasio Gini & 0,357 & 0,384 & $\begin{array}{l}\text { Kab. Kebumen } \\
\quad(0,28)^{*}\end{array}$ & $\begin{array}{c}\text { Kab. Blora } \\
(0,39)^{*}\end{array}$ \\
\hline IPM & 71,12 & 71,39 & $\begin{array}{l}\text { Kab. Pemalang } \\
(65,67)\end{array}$ & $\begin{array}{c}\text { Kota Semarang } \\
\quad(82,72)\end{array}$ \\
\hline
\end{tabular}

Sumber: BPS (2019)

Keterangan: *data tahun 2015

Studi ini dilakukan untuk menjawab dua pertanyaan. Pertama, bagaimana klasterisasi kabupaten/kota di Jawa Tengah berdasarkan capaian indikator kinerja pembangunan? Kedua, bagaimana karakteristik indikator kinerja pembangunan pada masing-masing klaster yang terbentuk? Pengambil kebijakan dapat menggunakan hasil studi ini dalam melaksanakan pembangunan berbasis wilayah guna mengatasi ketimpangan yang terjadi. Indikator kinerja diperoleh dari literatur dan studi empiris yang pernah dilakukan serta indikator kinerja penyelenggaraan pemerintahan daerah berdasarkan Permendagri RI Nomor 86/2017.

Principal Component Analysis (PCA) dan analisis faktor digunakan untuk mereduksi variabel kinerja pembangunan yang saling berkorelasi, sedangkan analisis cluster digunakan untuk melakukan klasterisasi kabupaten/kota berdasarkan indikator kinerja pembangunan. Hal ini memungkinkan adanya diskusi apakah ada kabupaten/kota yang kinerja pembangunannya tertinggal dibanding kabupaten/kota lain, yang pada gilirannya mengarah pada rekomendasi kebijakan regional. 


\section{METODE PENELITIAN Data dan Variabel}

Data yang digunakan berupa data sekunder yang dipublikasikan oleh BPS, Dinas Kesehatan Propinsi Jawa Tengah, dan Kementerian Keuangan. Data tersebut adalah PDRB, IPM, ketenagakerjaan, kemiskinan, Statistik Kesejahteraan Rakyat, Statistik Podes, Profil Kesehatan, dan pendapatan asli daerah (PAD).

Variabel yang digunakan dikelompokkan ke dalam tiga indikator kinerja. Pertama, indikator kinerja pembangunan manusia, meliputi: rata-rata lama sekolah (tahun), angka partisipasi sekolah (16-18 tahun), angka harapan hidup (tahun), penduduk yang tidak memiliki keluhan kesehatan (\%), bayi berat badan lahir normal (\%), pengeluaran per kapita disesuaikan (rupiah/orang/tahun), tingkat partisipasi angkatan kerja (\%), rasio penduduk yang bekerja (\%), jumlah penduduk (orang), dan penduduk di atas garis kemiskinan (\%). Kedua, indikator kinerja pembangunan infrastruktur, meliputi desa yang memiliki: bangunan puskesmas pembantu (\%), tempat praktek dokter (\%),sumber air minum sebagian besar keluarganya air kemasan/ledeng (\%), bank (\%), pasar dengan bangunan (\%), jalan yang dapat dilalui kendaraan roda empat sepanjang tahun (\%), jalan beraspal (\%), lembaga keterampilan (\%), sinyal telepon selulernya sangat kuat dan kuat (\%), saluran irigasi (\%), keluarga pengguna Listrik PLN (\%), dan SMP/MTs (\%). Sementara itu, variabel nilai investasi (juta rupiah), rasio keterbukaan perdagangan (\%), PDRB riil per kapita (rupiah), pertumbuhan ekonomi (\%), kontribusi PDRB kabupaten/kota terhadap provinsi (\%), kontribusi sektor tersier terhadap PDRB nominal (\%), PAD (juta rupiah), dan nilai impor (juta rupiah) merupakan variabel-variabel untuk menggambarkan indikator kinerja pembangunan ekonomi.

Perbedaan satuan pada variabel yang digunakan akan menyebabkan bias pada PCA dan analisis faktor. Oleh karenanya dilakukan standarisasi dengan cara mentransformasikan data asli (asal) ke dalam bentuk Z-score.

\section{Principal Component Analysis (PCA)}

PCA merupakan suatu analisis untuk membentuk variabel baru [principal component (PC)] yang tidak memiliki korelasi dengan mempertahankan sebanyak mungkin keragaman data dengan cara mengurangi banyaknya dimensi variabel yang memiliki korelasi. Supaya dapat ditafsirkan dengan baik maka penetapan banyaknya PC dapat dilihat dari nilai eigenvalue yang lebih besar dari 1. PCA pertama kali dikemukakan oleh Karl Pearson tahun 1901 yang kemudian dikembangkan oleh Harold Hotelling tahun 1933 (Jollife, 2002). Pagliacci, Pavone, Russo, \& Giorgi (2019) meneliti heterogenitas struktur regional di kawasan Uni Eropa berdasarkan 31 variabel makro kinerja pembangunan menggunakan PCA dan analisis cluster.

Pada analisis faktor, indikator dibentuk dari PC terpilih pada tahap sebelumnya. Kemudian, tahap berikutnya ialah melakukan uji matriks korelasi terhadap data, yaitu bartlett's test dan uji KMO (Keiser Meyer Olkin). Kedua uji ini juga digunakan untuk menguji kelayakan dari analisis faktor.

Langkah-langkah Bartlett's Test adalah sebagai berikut:

Pertama adalah menyusun hipotesis, yaitu:

$\mathrm{H}_{0}$ : matriks korelasi adalah matriks identitas

$\mathrm{H}_{1}$ : matriks korelasi bukan matriks identitas 
Kedua yaitu melakukan uji statistik seperti Rumus 1.

$\chi_{\mathrm{uji}}^{2}=-\left[(\mathrm{N}-1)-\frac{(2 \mathrm{p}+5)}{6}\right] \ln |\mathrm{R}|$

dengan: $\mathrm{N}$ = banyaknya observasi, $\mathrm{p}=$ banyaknya variabel, $|\mathrm{R}|=$ determinan matriks korelasi

Ketiga yaitu pengambilan keputusan dengan cara tolak $\mathrm{H}_{0}$ dan uji $\mathrm{KMO}$ dengan Rumus 2.

Tolak $\mathrm{H}_{0}$ jika $\chi_{\mathrm{uji}}^{2}>\chi_{\alpha, \mathrm{p}(\mathrm{p}-1) / 2}^{2}$
$\mathrm{KMO}=\frac{\sum_{\mathrm{i}} \sum_{\mathrm{i} \neq \mathrm{j}} \mathrm{r}_{\mathrm{ij}}^{2}}{\sum_{\mathrm{i}} \sum_{\mathrm{i} \neq \mathrm{j}} \mathrm{r}_{\mathrm{ij}}^{2}+\sum_{\mathrm{i}} \sum_{\mathrm{i} \neq \mathrm{j}} \mathrm{a}_{\mathrm{ij}}^{2}}$

dengan: $r_{i j}=$ koefisien korelasi sederhana antara variabel $\mathrm{i}$ dan $\mathrm{j}$; $\mathrm{a}_{\mathrm{ij}}=$ koefisien korelasi parsial antara variabel $\mathrm{i}$ dan $\mathrm{j} ; \mathrm{i}=1$, $2, \ldots, p ;$ dan $\mathrm{j}=1,2, \ldots, \mathrm{p}$.

Klasifikasi dan rekomendasi yang dapat diambil dari nilai KMO dapat dilihat pada Tabel 2.

Tabel 2.

Klasifikasi Nilai KMO

\begin{tabular}{cl}
\hline Nilai KMO & \multicolumn{1}{c}{ Rekomendasi } \\
\hline$\geq 0,90$ & Data sangat baik (marvelous) \\
$0,80-0,89$ & Data berguna (meritorious) \\
$0,70-0,79$ & Data biasa (middling) \\
$0,60-0,69$ & Data cukup (mediocre) \\
$0,50-0,59$ & Data buruk (miserable) \\
$\leq 0,50$ & Data tidak diterima (unacceptable) \\
\hline
\end{tabular}

Sumber: Widarjono (2015)

\section{Analisis Faktor}

Keterkaitan antar variabel asal dipilih dengan analisis faktor. Analisis ini memerlukan nilai estimasi dari faktor-faktor bersama yang disebut skor faktor. Fungsi skor faktor adalah untuk menunjukkan penting tidaknya peranan faktor-faktor tersebut terhadap observasi yang diteliti (Ekaria, 2004). Widaryoko (2011) menggunakan analisis ini untuk menentukan banyaknya faktor optimal yang terbentuk dari peubah kinerja pembangunan dalam pengelompokkan kabupaten/kota di Jawa Timur.

Model analisis faktor dapat dituliskan dengan Rumus 3.

$\mathrm{X}_{\mathrm{px} 1}-\mu_{\mathrm{px} 1}=\mathrm{L}_{\mathrm{pxm}} \mathrm{F}_{\mathrm{mx} 1}+\varepsilon_{\mathrm{px} 1}$

dengan: $X$ vektor variabel asal, $F$ vektor faktor bersama, $\mu$ vektor rata-rata variabel asal, L matriks faktor loading, dan $\varepsilon$ vektor faktor spesifik.
Model pada Rumus 3 adalah linier dalam faktor bersama. Bagian dari varian $\mathrm{X}_{\mathrm{i}}$ yang dapat diterangkan oleh faktor bersama disebut communality ke-i, sedangkan bagian dari varian $\mathrm{X}_{\mathrm{i}}$ karena faktor spesifik disebut varian spesifik ke-i (Widarjono, 2015).

\section{Analisis Cluster}

Pemisahan obyek ke dalam beberapa klaster yang memiliki sifat berbeda antar klaster dilakukan dengan analisis cluster. Variasi antar obyek dalam suatu klaster dibuat sehomogen mungkin. Armen (1972), Cullingford \& Openshaw (1982), Cullinan, Garvey, \& Keane (2013), dan Hedlund (2014) menggunakan analisis ini untuk mengelompokkan wilayah perkotaan dan perdesaan berdasarkan variabel kinerja pembangunan.

Klasterisasi obyek dilakukan dengan menggunakan ukuran kemiripan, berupa 
jarak euclidean. Jarak euclidean antara dua obyek (X, Y) yang berdimensi $\mathrm{p}$ dapat dihitung dengan Rumus 4.

$D_{(X, Y)}=\sqrt{\left(X_{1}-Y_{1}\right)^{2}+\left(X_{2}-Y_{2}\right)^{2}+\cdots+\left(X_{p}-Y_{p}\right)^{2}}$

Nilai $\mathrm{D}$ yang semakin kecil menunjukkan semakin mirip kedua obyek yang diamati.

Ada dua asumsi dalam analisis cluster yang harus dipenuhi. Pertama, asumsi nonmultikolinieritas dan seandainya ada besarnya multikolinieritas tersebut kurang dari 0,8 (Gujarati, 2004). Kedua, sampel yang diambil harus mewakili populasi.

Tahap berikutnya ialah menentukan metode klasifikasi/klasterisasi. Penelitian ini menggunakan metode non hierarki ( $K$ means Clustering). Metode ini bertujuan untuk mengklasterisasi data supaya jarak setiap data ke pusat klaster pada klaster yang sama minimum. Jarak euclidean antara individu ke-i dan klaster ke-g $[\mathrm{D}(\mathrm{i}, \mathrm{g})]$ dihitung dengan Rumus 5 .

$\mathrm{D}(\mathrm{i}, \mathrm{g})=\left(\sum_{\mathrm{j}=1}^{\mathrm{p}}(\mathrm{X}[\mathrm{i}, \mathrm{j}]-\overline{\mathrm{X}}[\mathrm{g}, \mathrm{j}])^{2}\right)^{1 / 2}$

dengan:

$\mathrm{X}(\mathrm{i}, \mathrm{j})=$ nilai dari individu ke-i dalam variabel ke-j

$\overline{\mathrm{X}}[\mathrm{g}, \mathrm{j}]=$ rata-rata variabel ke-j dalam klaster ke-g

Dari analisis cluster, diperoleh nilai mean dan standar deviasi variabel masingmasing klaster. Penelitian ini mengkategorikan variabel pada setiap klaster menjadi lima level, yakni: sangat rendah, rendah, sedang, tinggi, dan sangat tinggi. Penentuan level kategori tersebut mengacu pada penelitian Abdullah (2008) seperti ditampilkan pada Tabel 3 .

Tabel 3.

Kategori dan Nilai Selang Rata-rata Berbobot Skor Faktor (SF)

\begin{tabular}{lc}
\hline \multicolumn{1}{c}{ Kategori } & Nilai Selang \\
\hline Sangat tinggi & $\left(\overline{\mathrm{Y}}_{\mathrm{j}}+1,5 \mathrm{~S}_{\mathrm{j}}\right)<\mathrm{SF}$ \\
Tinggi & $\left(\overline{\mathrm{Y}}_{\mathrm{j}}+0,5 \mathrm{~S}_{\mathrm{j}}\right)<\mathrm{SF} \leq\left(\overline{\mathrm{Y}}_{\mathrm{j}}+1,5 \mathrm{~S}_{\mathrm{j}}\right)$ \\
Sedang & $\left(\overline{\mathrm{Y}}_{\mathrm{j}}-0,5 \mathrm{~S}_{\mathrm{j}}\right)<\mathrm{SF} \leq\left(\overline{\mathrm{Y}}_{\mathrm{j}}+0,5 \mathrm{~S}_{\mathrm{j}}\right)$ \\
Rendah & $\left(\overline{\mathrm{Y}}_{\mathrm{j}}-1,5 \mathrm{~S}_{\mathrm{j}}\right)<\mathrm{SF} \leq\left(\overline{\mathrm{Y}}_{\mathrm{j}}-0,5 \mathrm{~S}_{\mathrm{j}}\right)$ \\
Sangat rendah & $\mathrm{SF} \leq\left(\overline{\mathrm{Y}}_{\mathrm{j}}-1,5 \mathrm{~S}_{\mathrm{j}}\right)$ \\
\hline
\end{tabular}

Sumber: Abdullah (2008)

\section{HASIL DAN PEMBAHASAN}

Kinerja Pembangunan

Hasil pengolahan PCA dan analisis faktor pada ketiga indikator kinerja pembangunan diperoleh nilai KMO di atas 0,6 dan nilai Bartlett's Test dengan p-value
0,000 (di bawah taraf nyata 0,05 ) pada setiap indikator. Ini menunjukkan bahwa data pada ketiga indikator tersebut cukup untuk dilakukan analisis faktor. Hasil tersebut dapat dilihat pada Tabel 4. 
Tabel 4.

Nilai KMO dan Bartlett's Test Indikator Kinerja Pembangunan

\begin{tabular}{lccc}
\hline \multicolumn{1}{c}{ Indikator Kinerja } & Nilai KMO & $\begin{array}{c}\text { Nilai } \\
\text { Bartlett's Test }\end{array}$ & p-value \\
\hline Pembangunan manusia & 0,686 & 183,515 & 0,000 \\
Pembangunan infrastruktur & 0,768 & 304,280 & 0,000 \\
Pembangunan ekonomi & 0,636 & 372,045 & 0,000 \\
\hline
\end{tabular}

Sumber: hasil olah data

Kemampuan suatu faktor dalam tertinggi pada masing-masing indikator menerangkan keragaman suatu variabel kinerja pembangunan. Sebagai contoh, diukur dengan nilai communalities. Angka AHH memiliki nilai communalities 0,876; harapan hidup $(\mathrm{AHH})$, persentase jumlah artinya 87,6 persen keragamanan $\mathrm{AHH}$ desa yang terdapat tempat praktek dokter, dapat diterangkan oleh faktor yang dan nilai investasi, merupakan variabel- terbentuk.

variabel yang memiliki nilai communalities

Tabel 5.

Nilai Communalities Tertinggi Tiap Indikator Kinerja

\begin{tabular}{|c|c|c|}
\hline Variabel & Indikator Kinerja & $\begin{array}{c}\text { Nilai } \\
\text { Communalities }\end{array}$ \\
\hline Angka Harapan Hidup & Pembangunan manusia & 0,876 \\
\hline $\begin{array}{l}\text { Persentase jumlah desa yang terdapat } \\
\text { tempat praktek dokter }\end{array}$ & Pembangunan infrastruktur & 0,948 \\
\hline Nilai investasi & Pembangunan ekonomi & 0,970 \\
\hline
\end{tabular}

Sumber: hasil olah data

Selanjutnya, berdasarkan nilai sekolah (16-18 tahun), pengeluaran per eigenvalue $(\geq 1)$, jumlah optimal faktor kapita disesuaikan, dan persentase yang dapat dibentuk oleh indikator kinerja penduduk di atas garis kemiskinan. pembangunan manusia, infrastruktur, dan Sementara itu, Faktor 2 berkorelasi positif ekonomi masing-masing sebanyak 3, 3, dan dengan variabel tingkat partisipasi angkatan 2 faktor. Widaryoko (2011) yang meneliti kerja, persentase penduduk yang tidak pengelompokan kabupaten/kota di Jawa memiliki keluhan kesehatan, dan rasio Timur dengan menggunakan PCA dan penduduk yang bekerja, sedangkan Faktor 3 analisis faktor yang diterapkan pada 27 berkorelasi positif dengan persentase bayi variabel dapat membentuk 2 faktor kinerja berat badan lahir normal dan jumlah pembangunan sumberdaya manusia, 3 penduduk. Ketiga faktor yang terbentuk faktor kinerja pembangunan prasarana, dan sudah sesuai karena memiliki korelasi yang 2 faktor kinerja pembangunan ekonomi.

Pada indikator kinerja pembangunan manusia, Faktor 1 berkorelasi positif dengan variabel rata-rata lama sekolah, angka harapan hidup, angka partisipasi tinggi (di atas 0,5), yakni berturut-turut sebesar 0,935; 0,843; dan 0,902. Keragaman total yang dapat diterangkan ketiga faktor tersebut adalah sebesar $72,532 \%$. 
Indikator kinerja pembangunan infrastruktur terbentuk menjadi tiga faktor. Faktor 1 berkorelasi positif dengan variabel persentase jumlah desa yang terdapat: bangunan puskesmas pembantu, tempat praktek dokter, sumber air minum sebagian besar keluarganya air kemasan/ledeng, bank, pasar dengan bangunan, lembaga keterampilan, sinyal telepon selulernya sangat kuat dan kuat, dan SMP/MTs. Berikutnya, Faktor 2 berkorelasi positif dengan variabel persentase jumlah desa yang terdapat: keluarga pengguna listrik PLN dan jalan yang dapat dilalui kendaraan roda empat sepanjang tahun. Terakhir, Faktor 3 berkorelasi positif dengan variabel persentase jumlah desa dengan jalan beraspal dan terdapat saluran irigasi. Ketiga faktor yang terbentuk ini secara bersamasama dapat menerangkan keragaman total sebesar $72,727 \%$.

Secara lengkap hasil analisis tersebut ditampilkan pada Tabel 6.

Tabel 6.

Eigenvalue, Persentase Keragaman, dan Nilai Korelasi menurut Faktor yang Terbentuk pada Indikator Kinerja Pembangunan

\begin{tabular}{lccccc}
\hline $\begin{array}{c}\text { Indikator } \\
\text { Kinerja }\end{array}$ & Faktor & Eigenvalue & $\begin{array}{c}\text { Persentase } \\
\text { Keragaman }\end{array}$ & $\begin{array}{c}\text { Kumulatif } \\
\text { Persentase } \\
\text { Keragaman }\end{array}$ & $\begin{array}{c}\text { Nilai Korelasi } \\
\text { pada Diagonal } \\
\text { Utama }\end{array}$ \\
\hline Pembangunan & 1 & 3,785 & 37,846 & 37,846 & 0,935 \\
manusia & 2 & 2,101 & 21,010 & 58,856 & 0,843 \\
& 3 & 1,368 & 13,675 & 72,532 & 0,902 \\
\hline Pembangunan & 1 & 6,001 & 50,005 & 50,005 & 0,999 \\
infrastruktur & 2 & 1,461 & 12,173 & 62,178 & 0,971 \\
& 3 & 1,266 & 10,549 & 72,727 & 0,972 \\
\hline Pembangunan & 1 & 4,049 & 50,615 & 50,615 & 0,933 \\
ekonomi & 2 & 2,372 & 29,648 & 80,263 & 0,933 \\
\hline Sumber: & & & &
\end{tabular}

Sumber: hasil olah data

Indikator kinerja pembangunan ekonomi dapat membentuk 2 faktor. Faktor 1 berkorelasi positif dengan variabel nilai investasi, PDRB riil per kapita, kontribusi PDRB kabupaten/kota terhadap provinsi, PAD, dan nilai impor. Faktor 2 berkorelasi positif dengan pertumbuhan ekonomi dan kontribusi sektor tersier terhadap PDRB, serta berkorelasi negatif dengan rasio keterbukaan perdagangan. Keragaman total yang dapat diterangkan dari kedua faktor ini sebesar 80,263\%.

Keadaan setiap kabupaten/kota di Jawa Tengah berdasarkan variabel kinerja pembangunan dapat dijabarkan dengan menggunakan rata-rata berbobot dari skor faktor kinerja pembangunan manusia, infrastruktur, dan ekonomi. Tabel 7 memperlihatkan bahwa pada tahun 2018, rata-rata skor faktor kinerja pembangunan manusia tertinggi dicapai Kota Semarang $(1,22)$, diikuti Kota Salatiga $(1,01)$ dan Kabupaten Sukoharjo $(0,93)$. Capaian ini menunjukkan bahwa ketiga wilayah tersebut memiliki kualitas pembangunan manusia yang lebih baik dibanding 32 wilayah lainnya. Sementara itu, Kabupaten Brebes, Kabupaten Purbalingga, dan Kabupaten Wonosobo merupakan tiga 
daerah yang memiliki capaian skor faktor kinerja pembangunan manusia terendah.

Berdasarkan kinerja pembangunan infrastruktur, rata-rata skor faktor tertinggi tercatat di Kota Magelang (1,99) diikuti Kota Surakarta $(1,76)$, dan Kota Salatiga $(1,36)$. Pembangunan infrastuktur perdesaan di ketiga kota ini lebih baik dibanding 32 wilayah lainnya. Kinerja pembangunan infrastruktur kurang baik terjadi di Kabupaten Blora dimana nilai rata-rata skor faktornya -1,07. Angka ini menunjukkan masih rendahnya pembangunan infrastruktur di kabupaten ini dibanding wilayah lainnya. Kabupaten Temanggung dan Kabupaten Pekalongan juga mengalami kondisi kinerja pembangunan infrastruktur yang masih kurang baik.
Kota Semarang yang merupakan kota metropolitan juga menjadi daerah yang paling berhasil dalam pembangunan ekonomi. Rata-rata skor faktor kinerja pembangunan ekonominya mencapai 3,75. Posisi dibawahnya dicapai Kota Surakarta $(0,95)$ dan Kabupaten Banyumas (0,63). Di sisi lain, Kabupaten Kudus, Kabupaten Blora, dan Kabupaten Purbalingga mempunyai kinerja pembangunan ekonomi yang tidak lebih baik dibanding 32 wilayah lainnya. Sementara itu, dalam penelitian Widaryoko (2011), Kota Surabaya yang statusnya sama dengan Kota Semarang sebagai ibukota provinsi ditempatkan sebagai kota yang paling berhasil dalam pembangunan ekonomi dan prasarana.

Tabel 7.

Nilai Rata-rata Berbobot Skor Faktor Indikator Kinerja Pembangunan

\begin{tabular}{lcrrrrr}
\hline \multirow{2}{*}{ Kabupaten/Kota } & \multicolumn{2}{c}{ Faktor Kinerja } & \multicolumn{2}{c}{ Faktor Kinerja } & \multicolumn{2}{c}{ Faktor Kinerja } \\
& \multicolumn{2}{c}{ Pembangunan Manusia } & Pembangunan Infrastruktur & Pembangunan Ekonomi \\
\cline { 2 - 7 } & Rata-rata & Ranking & $\begin{array}{c}\text { Rata-rata } \\
\text { Skor }\end{array}$ & Ranking & $\begin{array}{c}\text { Rata-rata } \\
\text { Skor }\end{array}$ & Ranking \\
\hline Kab. Cilacap & $-0,30$ & 25 & $-0,53$ & 30 & $-0,47$ & 32 \\
Kab. Banyumas & $-0,46$ & 29 & $-0,01$ & 12 & 0,63 & 3 \\
Kab. Purbalingga & $-1,15$ & 34 & $-0,10$ & 15 & $-0,56$ & 33 \\
Kab. Banjarnegara & $-0,76$ & 31 & $-0,73$ & 31 & $-0,21$ & 27 \\
Kab. Kebumen & $-0,45$ & 28 & $-0,29$ & 22 & 0,01 & 10 \\
Kab. Purworejo & $-0,25$ & 23 & $-0,82$ & 32 & $-0,13$ & 19 \\
Kab. Wonosobo & $-0,92$ & 33 & $-0,39$ & 28 & $-0,43$ & 31 \\
Kab. Magelang & 0,02 & 18 & $-0,47$ & 29 & $-0,04$ & 15 \\
Kab. Boyolali & 0,37 & 10 & $-0,35$ & 26 & $-0,16$ & 23 \\
Kab. Klaten & 0,28 & 12 & $-0,07$ & 14 & 0,07 & 6 \\
Kab. Sukoharjo & 0,93 & 3 & 0,41 & 8 & 0,06 & 7 \\
Kab. Wonogiri & 0,52 & 8 & $-0,31$ & 23 & $-0,20$ & 26 \\
Kab. Karanganyar & 0,80 & 4 & 0,25 & 9 & $-0,12$ & 18 \\
Kab. Sragen & 0,06 & 17 & 0,04 & 11 & $-0,01$ & 13 \\
Kab. Grobogan & $-0,04$ & 20 & $-0,31$ & 24 & 0,02 & 9 \\
Kab. Blora & $-0,29$ & 24 & $-1,07$ & 35 & $-0,72$ & 34 \\
Kab. Rembang & $-0,30$ & 26 & $-0,36$ & 27 & $-0,06$ & 16 \\
Kab. Pati & 0,21 & 14 & $-0,35$ & 25 & 0,00 & 11 \\
Kab. Kudus & 0,65 & 6 & 0,63 & 6 & $-0,85$ & 35 \\
Kab. Jepara & 0,31 & 11 & $-0,16$ & 16 & 0,00 & 12 \\
\hline
\end{tabular}




\begin{tabular}{|c|c|c|c|c|c|c|}
\hline \multirow{2}{*}{ Kabupaten/Kota } & \multicolumn{2}{|c|}{$\begin{array}{c}\text { Faktor Kinerja } \\
\text { Pembangunan Manusia } \\
\end{array}$} & \multicolumn{2}{|c|}{$\begin{array}{c}\text { Faktor Kinerja } \\
\text { Pembangunan Infrastruktur }\end{array}$} & \multicolumn{2}{|c|}{$\begin{array}{c}\text { Faktor Kinerja } \\
\text { Pembangunan Ekonomi }\end{array}$} \\
\hline & $\begin{array}{l}\text { Rata-rata } \\
\text { Skor }\end{array}$ & Ranking & $\begin{array}{l}\text { Rata-rata } \\
\text { Skor }\end{array}$ & Ranking & $\begin{array}{c}\text { Rata-rata } \\
\text { Skor }\end{array}$ & Ranking \\
\hline Kab. Demak & 0,12 & 15 & 0,04 & 10 & $-0,35$ & 29 \\
\hline Kab. Semarang & 0,41 & 9 & $-0,03$ & 13 & 0,19 & 5 \\
\hline Kab. Temanggung & 0,07 & 16 & $-0,91$ & 34 & $-0,38$ & 30 \\
\hline Kab. Kendal & $-0,19$ & 22 & $-0,27$ & 21 & $-0,14$ & 20 \\
\hline Kab. Batang & 0,01 & 19 & $-0,25$ & 20 & $-0,34$ & 28 \\
\hline Kab. Pekalongan & $-0,18$ & 21 & $-0,84$ & 33 & $-0,19$ & 25 \\
\hline Kab. Pemalang & $-0,78$ & 32 & $-0,17$ & 17 & $-0,16$ & 22 \\
\hline Kab. Tegal & $-0,55$ & 30 & $-0,19$ & 18 & $-0,15$ & 21 \\
\hline Kab. Brebes & $-1,55$ & 35 & $-0,24$ & 19 & $-0,18$ & 24 \\
\hline Kota Magelang & 0,64 & 7 & 1,99 & 1 & 0,04 & 8 \\
\hline Kota Surakarta & 0,71 & 5 & 1,76 & 2 & 0,95 & 2 \\
\hline Kota Salatiga & 1,01 & 2 & 1,36 & 3 & $-0,04$ & 14 \\
\hline Kota Semarang & 1,22 & 1 & 0,86 & 5 & 3,75 & 1 \\
\hline Kota Pekalongan & 0,25 & 13 & 0,57 & 7 & $-0,11$ & 17 \\
\hline Kota Tegal & $-0,43$ & 27 & 1,29 & 4 & 0,29 & 4 \\
\hline Rata-rata (mean) & 0,00 & & 0,00 & & 0,00 & \\
\hline Standar Deviasi & 0,63 & & 0,72 & & 0,73 & \\
\hline
\end{tabular}

Sumber: hasil olah data

Karakteristik klaster yang lebih rinci Ini berarti rata-rata berbobot skor faktor diperoleh dengan mengklasifikasikan menunjukkan hasil pengamatan lebih baik semua wilayah dalam 5 klaster berdasarkan dibanding data asal. Dengan demikian, capaian kinerja pembangunan manusia, proses klasterisasi dapat dilakukan dengan infrastruktur, dan ekonomi. Tabel 8 rata-rata skor faktor. Asumsi nonmenginformasikan bahwa persentase multikolinieritas juga terpenuhi karena nilai korelasi sedang dan besar indikator- korelasi di antara ketiga rata-rata skor indikator dari setiap variabel kinerja faktor variabel kinerja pembangunan di pembangunan berada di bawah 80 persen. bawah 0,8 (Tabel 9).

Tabel 8 .

Korelasi Sedang dan Besar pada Data Asal Indikator Kinerja Pembangunan

\begin{tabular}{lccc}
\hline \multicolumn{1}{c}{ Indikator Kinerja } & $\begin{array}{c}\text { Banyaknya } \\
\text { Korelasi Sedang } \\
\mid \text { 0,31 s.d. 0,75 }\end{array}$ & $\begin{array}{c}\text { Banyaknya } \\
\text { Korelasi Besar } \\
\mid \text { 0,76 s.d. 1,00 } \mid\end{array}$ & $\begin{array}{c}\text { Persentase } \\
\text { Korelasi Sedang } \\
\text { dan Besar }\end{array}$ \\
\hline Pembangunan manusia & 44 & 2 & 51,11 \\
Pembangunan infrastruktur & 58 & 12 & 64,81 \\
Pembangunan ekonomi & 26 & 12 & 67,86 \\
\hline
\end{tabular}

Sumber: hasil olah data 
Tabel 9.

Matriks Korelasi Nilai Rata-rata Berbobot Skor Faktor Indikator Kinerja Pembangunan

\begin{tabular}{lccc}
\hline \multicolumn{1}{c}{ Indikator Kinerja } & $\begin{array}{c}\text { Pembangunan } \\
\text { Manusia }\end{array}$ & $\begin{array}{c}\text { Pembangunan } \\
\text { Infrastruktur }\end{array}$ & $\begin{array}{c}\text { Pembangunan } \\
\text { Ekonomi }\end{array}$ \\
\hline Pembangunan Manusia & 1,000 & 0,509 & 0,400 \\
Pembangunan Infrastruktur & 0,509 & 1,000 & 0,391 \\
Pembangunan Ekonomi & 0,400 & 0,391 & 1,000 \\
\hline
\end{tabular}

Sumber: hasil olah data

Setelah syarat untuk melakukan bawah dan atas setiap kategori (Tabel 10). klasterisasi terpenuhi, proses selanjutnya Nilai batas bawah dan atas rata-rata ialah menyusun 5 kategori pada setiap berbobot skor faktor yang telah disusun indikator kinerja pembangunan. Kategori digunakan untuk mengkategori setiap disusun menggunakan nilai mean dan indikator kinerja pembangunan pada standar deviasi dari rata-rata berbobot skor masing-masing klaster (Tabel 11). faktor untuk memperoleh batas selang

Tabel 10.

Nilai Batas Selang Rata-rata Berbobot Skor Faktor (SF) Indikator Kinerja Pembangunan

\begin{tabular}{lccc}
\hline \multirow{2}{*}{ Kategori } & \multicolumn{3}{c}{ Rata-rata Skor Faktor (SF) } \\
\cline { 2 - 4 } & $\begin{array}{c}\text { Pembangunan } \\
\text { Manusia }\end{array}$ & $\begin{array}{c}\text { Pembangunan } \\
\text { Intrastruktur }\end{array}$ & $\begin{array}{c}\text { Pembangunan } \\
\text { Ekonomi }\end{array}$ \\
\hline Sangat tinggi (ST) & $0,94<\mathrm{SF}$ & $1,08<\mathrm{SF}$ & $1,10<\mathrm{SF}$ \\
Tinggi (T) & $0,31<\mathrm{SF} \leq 0,94$ & $0,36<\mathrm{SF} \leq 1,08$ & $0,37<\mathrm{SF} \leq 1,10$ \\
Sedang (S) & $-0,31<\mathrm{SF} \leq 0,31$ & $-0,36<\mathrm{SF} \leq 0,36$ & $-0,37<\mathrm{SF} \leq 0,37$ \\
Rendah (R) & $-0,94<\mathrm{SF} \leq-0,31$ & $-1,08<\mathrm{SF} \leq-0,36$ & $-1,10<\mathrm{SF} \leq-0,37$ \\
Sangat Rendah (SR) & $\mathrm{SF} \leq-0,94$ & $\mathrm{SF} \leq-1,08$ & $\mathrm{SF} \leq-1,10$ \\
\hline
\end{tabular}

Sumber: hasil olah data

Tabel 11.

Nilai Rata-rata Berbobot Skor Faktor (SF) dan Kategori menurut Klaster dan Indikator Kinerja Pembangunan

\begin{tabular}{ccccccc}
\hline \multirow{2}{*}{ Klaster } & \multicolumn{2}{c}{$\begin{array}{c}\text { Pembangunan } \\
\text { Manusia }\end{array}$} & \multicolumn{2}{c}{$\begin{array}{c}\text { Pembangunan } \\
\text { Intrastruktur }\end{array}$} & \multicolumn{2}{c}{$\begin{array}{c}\text { Pembangunan } \\
\text { Ekonomi }\end{array}$} \\
\cline { 2 - 7 } & SF & Kategori & SF & Kategori & SF & Kategori \\
\hline 1 & 0,71 & $\mathrm{~T}$ & 1,76 & $\mathrm{ST}$ & 0,95 & $\mathrm{~T}$ \\
2 & 1,22 & $\mathrm{ST}$ & 0,86 & $\mathrm{~T}$ & 3,75 & $\mathrm{ST}$ \\
3 & $-1,55$ & $\mathrm{SR}$ & $-0,24$ & $\mathrm{~S}$ & $-0,18$ & $\mathrm{~S}$ \\
4 & $-0,29$ & $\mathrm{~S}$ & $-1,07$ & $\mathrm{R}$ & $-0,72$ & $\mathrm{R}$ \\
5 & 0,65 & $\mathrm{~T}$ & 0,63 & $\mathrm{~T}$ & $-0,85$ & $\mathrm{R}$ \\
\hline
\end{tabular}

Sumber: hasil olah data

Proses identifikasi apakah indikator kinerja pembangunan dapat membedakan antar klaster dilakukan dengan uji Anova.
Tabel 12 memperlihatkan bahwa nilai $p$ value pada setiap rata-rata berbobot skor faktor kinerja pembangunan sebesar 0,000 
(di bawah taraf nyata 0,05 ). Hal ini berarti indikator kinerja pembangunan manusia, infrastruktur, dan ekonomi dapat membedakan karakteristik masing-masing klaster yang terbentuk. Angka statistik uji F terbesar ada pada skor faktor kinerja pembangunan infrastruktur yang tercatat 41,639. Ini berarti kinerja pembangunan infrastruktur yang paling membedakan karakteristik dari 5 klaster wilayah yang terbentuk. Hasil klasterisasi kabupaten/kota di Jawa Tengah dapat dilihat pada Tabel 13.

Tabel 12.

Hasil Uji Anova

\begin{tabular}{|c|c|c|c|c|}
\hline \multirow{2}{*}{ Variabel } & \multicolumn{2}{|c|}{ Mean Square } & \multirow{2}{*}{$\begin{array}{c}\text { Statistik } \\
\text { Uji F }\end{array}$} & \multirow{2}{*}{$\begin{array}{c}p- \\
\text { value }\end{array}$} \\
\hline & Cluster & Error & & \\
\hline $\begin{array}{l}\text { Rata-rata berbobot skor faktor pembangunan } \\
\text { manusia }\end{array}$ & 2,536 & 0,106 & 23,951 & 0,000 \\
\hline $\begin{array}{l}\text { Rata-rata berbobot skor faktor pembangunan } \\
\text { infrastruktur }\end{array}$ & 3,758 & 0,090 & 41,639 & 0,000 \\
\hline $\begin{array}{l}\text { Rata-rata berbobot skor faktor pembangunan } \\
\text { ekonomi }\end{array}$ & 3,833 & 0,094 & 40,640 & 0,000 \\
\hline
\end{tabular}

Sumber: hasil olah data

Tabel 13.

Klasterisasi Kabupaten/Kota di Jawa Tengah

\begin{tabular}{lccccc}
\hline \multicolumn{1}{c}{$\begin{array}{c}\text { Indikator } \\
\text { Kinerja }\end{array}$} & Klaster 1 & Klaster 2 & Klaster 3 & Klaster 4 & Klaster 5 \\
\cline { 2 - 6 } $\begin{array}{l}\text { Pembangunan } \\
\text { manusia }\end{array}$ & Tinggi & $\begin{array}{c}\text { Sangat } \\
\text { tinggi }\end{array}$ & $\begin{array}{l}\text { Sangat } \\
\text { rendah }\end{array}$ & Sedang & Tinggi \\
\hline $\begin{array}{l}\text { Pembangunan } \\
\text { infrastruktur }\end{array}$ & $\begin{array}{c}\text { Sangat } \\
\text { tinggi }\end{array}$ & Tinggi & Sedang & Rendah & Tinggi \\
\hline $\begin{array}{l}\text { Pembangunan } \\
\text { ekonomi }\end{array}$ & \multicolumn{1}{c}{ Tinggi } & Sangat & Sedang & Rendah & Rendah \\
\hline Anggota & Kota & Kota & Banyumas & Cilacap & Boyolali \\
& Magelang & Semarang & Purbalingga & Kebumen & Klaten \\
& Kota & & Banjarnegara & Purworejo & Sukoharjo \\
& Surakarta & & Wonosobo & Magelang & Wonogiri \\
& Kota & & Pemalang & Grobogan & Karangany \\
& Salatiga & & Tegal & Blora & ar Sragen \\
& Kota Tegal & & Brebes & Rembang & Kudus \\
& & & Pati & Jepara \\
& & & Temanggung & Demak \\
& & & Kendal & Semarang \\
& & & Batang & Kota \\
& & & Pekalongan & Pekalongan \\
\hline
\end{tabular}

Sumber: hasil olah data 
Tabel 13 memperlihatkan bahwa yang mengalami kemajuan dan sebagian besar kabupaten/kota di Jawa ketertinggalan pada masing-masing Tengah berada pada kluster 4 yang indikator kinerja, baik pembangunan memiliki karakteristik indikator kinerja manusia, infrastruktur, maupun ekonomi.

pembangunan manusia sedang, Berdasarkan hasil analisis cluster, 35 infrastruktur rendah, dan ekonomi rendah. kabupaten/kota dapat diklasterisasi ke Sementara itu, hasil penelitian Widaryoko dalam 5 klaster. Setiap klaster memiliki (2011) yang dilakukan di Jawa Timur karakteristik yang homogen, sedangkan menyimpulkan bahwa sebagian besar kabupaten/kotanya berada pada klaster dengan karakteristik pembangunan sumberdaya manusia sedang, prasarana sedang, dan ekonomi sedang.

\section{SIMPULAN}

Dari hasil penelitian dapat disimpulkan bahwa terjadi variasi kinerja pembangunan antarkabupaten/kota di Jawa Tengah. Ada antar klaster heterogen.

Pemerintah dapat menggunakan dan mempertimbangkan hasil penelitian ini dalam menentukan strategi yang tepat untuk membangun daerahnya sesuai dengan karakteristik dan potensi yang dimiliki sehingga ketimpangan hasil pembangunan dengan kabupaten/kota lain yang sudah maju dapat diperkecil.

\section{DAFTAR PUSTAKA}

Abdullah. (2008). Hubungan kecerdasan emosional dengan stres kerja pada polisi lalulintas di Kota Malang. Malang: UIN.

Armen, G. (1972). A classification of cities and city regions in England and Wales, 1966. Regional Studies. 6(2).149-182.

Badan Pusat Statistik. (2019). Statistik Indonesia 2019. Jakarta: Badan Pusat Statistik.

Badan Pusat Statistik. https://www.bps.go.id/subject/23/kemiskinan-danketimpangan.html\#subjekViewTab3. Internet. Diakses tanggal 1 Februari 2020.

Badan Pusat Statistik Provinsi Jawa Tengah. (2018). Statistik kesejahteraan rakyat Provinsi Jawa Tengah 2018. Semarang: Badan Pusat Statistik Provinsi Jawa Tengah.

Badan Pusat Statistik Provinsi Jawa Tengah. (2019). Statistik potensi desa Provinsi Jawa Tengah 2018. Semarang: Badan Pusat Statistik Provinsi Jawa Tengah.

Badan Pusat Ptatistik Javinsi Tengah. https://jateng.bps.go.id/subject/23/kemiskinan.html\#subjekViewTab3. Internet. Diakses tanggal 1 Februari 2020.

Cullinan, J., Garvey, E., \& Keane, M. (2013). Investigating the determinants of relative economic performance for irish towns: A finite mixture modelling approach. Regional Studies 47(8).1332-1347.

Cullingford, D., \& Openshaw, S. (1982). Identifying areas of rural deprivation using social area analysis. Regional Studies. 16(6).409-417.

Dadibhavi, R. V. (2019). Regional disparities, growth and divergence in income in Karnataka. Review of Development and Change. 24(1).55-78. 
Dinas Kesehatan Provinsi Jawa Tengah. (2019). Profil kesehatan Provinsi Jawa Tengah tahun 2018. Semarang: Dinas Kesehatan Provinsi Jawa Tengah.

Direktorat Jenderal Perimbangan Keuangan Kementerian Keuangan Republik Indonesia. http://www.djpk.kemenkeu.go.id/?p=5412. Internet. Diakses tanggal 1 Februari 2020.

Ekaria. (2004). Modul pelatihan analisis multivariate. Jakarta: BPKP-STIS.

Goletsis, Y., \& Chletsos, M. (2011). Measurement of development and regional disparities in Greek periphery: A multivariate approach. Socio-Economic Planning Sciences. 45(4).174-183.

Gujarati, D.N. (2004). Basic econometrics (4th ed.). New York: The McGraw-Hill Companies.

Hedlund, M. (2014). Mapping the socioeconomic landscape of rural Sweden: Towards a typology of rural areas. Regional Studies. 50(3).460-474.

Jolliffe, I.T. (2002). Principal component analysis (2nd ed.). New York: Springer.

Kronthaler, F. (2005). Economic capability of East German regions: Results of a cluster analysis. Regional Studies. 39(6).739-750.

Pagliacci, F., Pavone, P., Russo, M., \& Giorgi, A. (2019). Regional structural heterogeneity: evidence and policy implications for RIS3 in macro-regional strategies. Regional Studies. 1-11.

Pompili, T. (1994). Structure and performance of less developed regions in the EC. Regional Studies. 28(7).679-693.

Spencer G.M., Vinodrai T., Gertler M.S. and Wolfe D.A. (2009). Do clusters make a difference? Defining and assessing their economic performance. Regional Studies. 44(6).697-715.

Tarigan, R. (2005). Ekonomi regional, teori dan aplikasi. Jakarta: Bumi Aksara.

Todaro, M.P., \& Smith, S.C. (2012). Economic development (11th ed.). United Kingdom: Pearson Education Limited.

Widarjono, A. (2015). Analisis multivariat terapan. Yogyakarta: UPP STIM YKPN.

Widaryoko, N. (2011). Analisis klasifikasi kabupaten/kota di Provinsi Jawa Timur berdasrkan peubah kinerja pembangunan daerah tahun 2010. Bogor: IPB.

Yamin, S., \& Kurniawan, H. (2009). SPSS complete. Jakarta: Salemba Infotek. 